\title{
OPTIMIZATION PROCESS FOR THE REMOVAL OF HEAVY METALS FROM AQUEOUS SOLUTION USING GRAPHENE OXIDE NANOSHEETS AND RESPONSE SURFACE METHODOLOGY
}

\author{
Rouniasi, N. ${ }^{1}$ - MONAVVARI, S. M. ${ }^{1 *}$ - ABDOLI, M. A. ${ }^{2}$ - BAGHDADI, M. ${ }^{2}-$ KARBASSI, A. R. ${ }^{2}$ \\ ${ }^{I}$ Department of Environment, Faculty of Natural Resources and Environment, Science and \\ Research Branch, Islamic Azad University, Tehran, Iran \\ ${ }^{2}$ School of Environment, College of Engineering, University of Tehran, Tehran, Iran \\ *Corresponding author \\ e-mail: monavarism@yahoo.com; phone/fax: +98-21-8823-3144 \\ (Received $3^{\text {rd }}$ Jul 2018; accepted $31^{\text {st }}$ Aug 2018)
}

\begin{abstract}
Water pollution due to heavy metals has become a critical problem worldwide. In this study, the removal of chromium(III), cadmium and lead by graphene oxide adsorbent was examined. Graphene oxide nanosheets were synthesized through Hummer's method, and their characteristics were examined using FTIR, XRD, and SEM. The effect of independent variables, $\mathrm{pH}$, contact time and initial concentration of solution on the removal efficiency of $\mathrm{Cr}(\mathrm{III}), \mathrm{Cd}^{2+}$ and $\mathrm{Pb}^{2+}$ was evaluated according to the experimental Box-Behnken Design using response surface methodology (RSM). Applying quadratic model, the adsorption rate of $\mathrm{Cd}^{2+}$ and $\mathrm{Pb}^{2+}$ was obtained as $99 \%$ and the adsorption rate of $\mathrm{Cr}(\mathrm{III})$ was obtained as $98 \%$. ANOVA was applied as statistical analysis of responses. According to FESEM images, the average size of graphene oxide sheets was 1 to $3 \mu \mathrm{m}$. After optimization by RSM, adsorption capacities of $\mathrm{Cr}(\mathrm{III}), \mathrm{Pb}^{2+}$ and $\mathrm{Cd}^{2+}$ were found to be $38 \mathrm{mg} / \mathrm{g}, 136 \mathrm{mg} / \mathrm{g}$ and $68 \mathrm{mg} / \mathrm{g}$, respectively. Examination of isotherms suggested that $\mathrm{Cd}^{2+}$ and $\mathrm{Cr}(\mathrm{III})$ adsorptions follow Langmuir, and $\mathrm{Pb}^{2+}$ adsorption follows Freundlich isotherm. The results showed that graphene oxide has a good effect on removing $\mathrm{Cr}(\mathrm{III}), \mathrm{Cd}^{2+}$ and $\mathrm{Pb}^{2+}$ ions from aqueous solutions. $\mathrm{pH}$ of the solution and initial concentration of the contaminant had the highest effect on adsorption of the mentioned heavy metals. The results of RSM analysis showed that the obtained data were in agreement with the predicted model.
\end{abstract}

Keywords: adsorption, water pollution, heavy metals, Box-Behnken Design, Langmuir, Freundlich

Abbreviations: GO: Geraphene oxid; RSM: Response surface methodology; FTIR: Fourier transform infrared; XRD: X-ray diffraction; SEM: scanning electron microscope; FESEM: Field Emission Scanning Electron Microscope; BBD: Box-Behnken Design; EPA: Environmental Protection Agency ; $\mathrm{Cr}$ : Chromium; $\mathrm{Cd}$ : Cadmium; $\mathrm{Pb}$ : Lead; $\mathrm{pH}$ : potential hydrogen; Conc: Concentration; PZC: point of zero charge

\section{Introduction}

Growth of urbanization, rapid industrialization of cities and emission of heavy metals in the ecosystem - even at extremely low concentrations - have brought up concerns worldwide. Removal of heavy metals from water and wastewater has been at the center of attention owing to strict regulations on water pollution control in many countries (Amarasinghe and Williams, 2007). Lead, chromium, cadmium, zinc, and nickel are among the most water polluting heavy metals (Yang et al., 2014). Conventional methods for the removal of heavy metals from water include chemical oxidation, chemical precipitation, ion exchange, adsorption, filtration, reverse osmosis, solvent extraction and coagulation-flocculation (Rajasulochana 
and Preethy, 2016). Adsorption method is known to be better than other techniques due to high efficiency, flexibility, simple design, low cost, easy operation and minimum sludge production ( $\mathrm{Fu}$ and Wang, 2011). The most important characteristics for an adsorbent are high adsorption capacity and rapid adsorption. These can be achieved when the adsorbent possesses a large specific surface area and abundant adsorption sites (Wang et al., 2012). Majority of adsorbents rarely have both of the mentioned characteristics. Therefore, an investigation on new adsorbents which can properly adsorb heavy metals is required (Pan et al., 2009). Among the studied adsorbents, graphene oxide nanoparticles, owing to adsorption capacity and large specific surface area, are applied either independently or along with other adsorbents in order to remove heavy metals from aqueous solutions (Liu et al., 2011; McGrail et al., 2016). Considerable physical properties of graphene include heat superconductivity, extremely high electron mobility (Jiang et al., 2010), high mechanical strength (Yu et al., 2008) and adsorption of some metal ions (Hao et al., 2012). Sitko et al. (2013) examined the adsorption of heavy metal ions from aqueous solutions using graphene oxide, and observed that maximum adsorption occurred at $\mathrm{pH}$ ranges of 4-8 for cadmium and 3-7 for lead and chromium. Fan et al. (2013) examined a mixture of graphene oxide and magnetic chitosan (MCGO) as an adsorbent and reached a maximum adsorption capacity of 96\% for lead ions. Kumar et al. (2014) studied the removal of lead and arsenic using graphene oxide nanosheets and concluded that graphene oxide is highly efficient in removing heavy metals from aqueous solutions. Among the contaminants, chromium(III), cadmium and lead are the most environmentpolluting elements since they are widely used in industry. The efficiency of adsorption processes depends on various parameters such as $\mathrm{pH}$, temperature, type of adsorbent, adsorbent dosage and organic or inorganic contaminants (Liu et al., 2011). The water containing high concentration of chromium may cause serious environmental problems and also skin sensitivity, cancer and DNA damage to humans (Tchounwou et al., 2012). Cadmium is categorized as a carcinogenic element, which leads to lung cancer, kidney diseases, digestive and immune system disorders in human bodies (Jaishankar et al., 2014). According to EPA, lead, after entering the body, does not leave the body and precipitates in blood, skin, organs and tissues including muscles, bones and joints (Huang et al., 2014; Li et al., 2007) and causes environmental pollution with severe toxic effects on human health and other creatures (Uluozlu et al., 2008).

The conducted studies show that graphene oxide nanosheets are the most effective adsorbents used for the removal of heavy metals from aqueous environments and soil. The key reason for using graphene oxide nanosheets in this study is their simultaneous possession of several properties.

In this study, the efficiency of graphene oxide nanosheets in removing chromium(III), cadmium and lead from aqueous solutions was examined. The aim of this study was to evaluate the effect of $\mathrm{pH}$, initial concentration and contact time on graphene oxide adsorption capacity. The variables analyzed by response surface method (RSM) were applied according to Box-Behnken design in order to optimize heavy metals removal from aqueous solutions. Also, absorption isotherm was investigated using Langmuir and Freundlich adsorption isotherms. 


\section{Materials and methods}

\section{Materials and instruments}

Chemicals applied in the experiments were lab grade. All the chemicals including nitric acid $65 \%\left(\mathrm{HNO}_{3}\right)$, sulfuric acid $97 \%\left(\mathrm{H}_{2} \mathrm{SO}_{4}\right)$, hydrogen peroxide $30 \%\left(\mathrm{H}_{2} \mathrm{O}_{2}\right)$, hydrochloric acid $(\mathrm{HCl})$, sodium hydroxide $(\mathrm{NaOH})$, sodium nitrate $\left(\mathrm{NaNO}_{3}\right)$, sodium chloride $(\mathrm{NaCl})$, chromium(III) chloride $\left(\mathrm{CrCl}_{3}\right)$, potassium dichromate $\left(\mathrm{K}_{2} \mathrm{Cr}_{2} \mathrm{O}_{7}\right)$, potassium permanganate $\left(\mathrm{KMnO}_{4}\right)$, lead nitrate $\left(\mathrm{PbNO}_{3}\right)$ and graphite powder were provided by Merck, Germany. Deionized water was used in all the experiments. Synthesis of graphene oxide nanosheets was done using Hettich centrifuge (Model Universal 320 R), an ultrasonic bath (Elmasonic, E 60H Model, Germany) and a heater (IKA 2000 Model, Germany). Moreover, $\mathrm{pH}$ was determined by a $\mathrm{pH}$-meter ( $\mathrm{pH}$-Meter 765, Germany), and agitation of the samples was carried out using an IKA-werke-KS260C shaker, Germany. The samples containing $\mathrm{Cr}(\mathrm{III}), \mathrm{Cd}^{2+}$ and $\mathrm{Pb}^{2+}$ ions were analyzed through ICP (Inductively Coupled Plasma) Varian-OES-710.

\section{Synthesis of graphene oxide}

Using the modified Hummer's method (which is suitable to synthesize graphene oxide), the synthesis of graphene oxide was carried out as follows. Initially, $200 \mathrm{~mL}$ concentrated sulfuric acid was poured into a $500 \mathrm{~mL}$ glass container and its temperature decreased after stirring in an ice-water bath for $30 \mathrm{~min}$. Then, $4 \mathrm{~g}$ of sodium nitrate was added to the solution and its temperature decreased after stirring in an ice-water bath for 1 h. Afterward, $4 \mathrm{~g}$ of graphite ( $500 \mathrm{mesh}$ ) was added and mixed for $2 \mathrm{~h}$ in this condition. 4 $\mathrm{g}$ of graphite (500 mesh) was added to the solution and then mixed for $2 \mathrm{~h}$. During $2 \mathrm{~h}, 24$ $\mathrm{g}$ of potassium permanganate was added and stirred. The glass container containing the sample was fixed in an oil bath at 38 to $40{ }^{\circ} \mathrm{C}$ for $24 \mathrm{~h}$. After removing the oil bath, 640 $\mathrm{mL}$ double distilled water was added to reaction container and stirred for $30 \mathrm{~min}$. The reaction stopped by adding $140 \mathrm{~mL}$ hydrogen peroxide $30 \%$. The sample was totally settled after three days. After removing the supernatant, the produced graphene oxide was washed four times using $\mathrm{HCl}(5 \%)$ and then filtered through a buchner funnel. The obtained suspension was washed four times using double distilled water. Then the suspension was treated by ultrasound for $30 \mathrm{~min}$. Finally, the obtained brown solid substance was dried in a vacuum oven at $40{ }^{\circ} \mathrm{C}$ (Chaiyakun et al., 2012).

\section{Determination of PZC}

In order to examine the heavy metals removal more closely, $\mathrm{pH}$ of the zero charge point, where the adsorbent surface is electrically neutral and unladen, and also the adsorbent PZC ( $\mathrm{pH}_{\mathrm{PZC}}$ ) were measured (Zhao et al., 2011, 2012). In order to measure PZC, 10 flasks containing $0.1 \mathrm{~mol} / \mathrm{L} \mathrm{NaCl}$ solution were used. The initial $\mathrm{pH}$ of the solution was adjusted in the range of 1 to 10 using $\mathrm{NaOH}$ and $\mathrm{HCl} 0.1 \mathrm{~mol} / \mathrm{L}$. Then, $0.1 \mathrm{~g}$ adsorbent was added to each solution, and the electrolyte solution was stirred with the adsorbent for $24 \mathrm{~h}$. After reaching equilibrium, $\mathrm{pH}$ of the solutions was measured, $\Delta \mathrm{pH}$ graph was drawn according to the initial $\mathrm{pH}$, and $\mathrm{pH}_{\mathrm{PZC}}$ was estimated.

\section{Characterization of graphene oxide nanosheets}

Morphology, size and shape of the synthesized adsorbent were examined using a field emission scanning electron microscope (FESEM model MIRA3, TESCAN). 
Characteristics of graphene oxide nanoparticles were determined using an x-ray diffraction model: X'Pert PRO MPD PANalytical. Fourier transform infrared (FTIR) of graphene oxide in the range of $400-4000 \mathrm{~cm}^{-1}$ was analyzed using Bruker, Tensor 27 , Germany.

\section{Adsorption experiments}

All the experiments were conducted in a batch mode. Initially, the solutions containing $\mathrm{Cr}(\mathrm{III}), \mathrm{Cd}^{2+}$ and $\mathrm{Pb}^{2+}$ were prepared by adding a certain amount of potassium dichromate, cadmium nitrate and lead nitrate to $1 \mathrm{~L}$ of DI water. In order to study the effect of environmental $\mathrm{pH}$ on adsorbing metals within the range of 2-6, $0.05 \mathrm{~g} / \mathrm{L}$ and $0.02 \mathrm{~g} / \mathrm{L}$ of the synthesized graphene oxide were added to the lead and cadmium-containing solutions and chromium-containing solution, respectively (the initial concentration was within the ranges of $10-100 \mathrm{mg} / \mathrm{L}$ for $\mathrm{Cd}^{2+}$ and $\mathrm{Cr}$ (III) and 50$150 \mathrm{mg} / \mathrm{L}$ for lead, and contact time of 5-60 min was allotted to each metal). The solutions were studied by the presented model and stirred on a magnetic stirrer with a constant speed of $200 \mathrm{rpm}$ for a specified time. Finally, the solutions were stabilized as the mentioned time passed. At the next step, the suspension was filtered by centrifugal method and passed through $0.2 \mu \mathrm{m}$ filters. The heavy metals concentration after adsorption was measured using ICP. Adsorption efficiencies of $\mathrm{Cr}(\mathrm{III}), \mathrm{Pb}^{2+}$ and $\mathrm{Cd}^{2+}$ were calculated by Equation 1 (Belay et al., 2010).

$$
\mathrm{R}=\frac{\left(\mathrm{C}_{0}-\mathrm{C}_{\mathrm{e}}\right)}{\mathrm{C}_{\mathrm{o}}} * 100
$$

Moreover, adsorption capacity of the synthesized graphene oxide at various heavy metals concentrations was determined using Equation 2 (Li et al., 2011).

$$
\mathrm{Qe}=\frac{\left(\mathrm{c}_{\mathrm{o}}-\mathrm{C}_{\mathrm{e}}\right) \mathrm{V}}{\mathrm{m}}
$$

where, $\mathrm{R}$ is adsorption removal efficiency, Qe is the amount of the heavy metal adsorbed onto the adsorbent in equilibrium conditions $(\mathrm{mg} / \mathrm{g}), \mathrm{C}_{0}$ is the initial concentration of the heavy metal in solution $(\mathrm{mg} / \mathrm{L}), \mathrm{C}_{\mathrm{e}}$ indicates equilibrium concentration of the heavy metal after equilibrium time elapsing $(\mathrm{mg} / \mathrm{L}), \mathrm{V}$ is volume of the solution in liter, and $\mathrm{m}$ is mass of the adsorbent in gram.

\section{Experimental design and data analysis}

RSM along with experimental techniques was used to assess the relationship among the effective variables in the experiment (Ghafari et al., 2009). ANOVA was applied as a statistical method for analysis of responses. Response surface method was applied according to Box-Behnken design in order to optimize heavy metals removal from aqueous solutions. This method has several advantages such as reducing the number of test steps, time and cost, and saving the consumption materials. This method is used in this study because it can 1) test several levels of testing with different factors, 2) identify how removal efficiencies are affected by changes in the level of $\mathrm{pH}$, initial concentration and contact time (as factors), and 3) specify the optimized combination of adsorbent $\mathrm{pH}$, initial concentration and contact time for the efficient removal of heavy metals. 
In this study, $\mathrm{pH}$ of the solution, concentration of contaminants and contact time were chosen as the independent variables affecting the heavy metals removal efficiency and labeled as $\mathrm{pH}(\mathrm{pH})$, concentration (conc) and contact time (Time), respectively (Tables $1 A, 2 B$, and $3 A$ ). Version 10 of Design-Expert software was used to investigate the effect of independent variables on response surface methodology (adsorption capacity of adsorbent and adsorption efficiency of heavy metals). Designing was carried out using the Box-Behnken design. The number of steps in the experiment was determined using Equation 3:

$$
N=2 K(K-1)+C_{o}
$$

where, $\mathrm{K}$ represents the number of factors investigated and $\mathrm{C}_{\mathrm{o}}$ indicates the number of replication for the experiment (Khajeh, 2011). 17 experiments with five replicates at center points were done for each metal. Thus, totally 51 experiments were designed and conducted (Yetilmezsoy et al., 2009). A second-order polynomial regression model equation, which relates the removal efficiency to the investigated factors, can be presented as Equation 4:

$$
Y=C_{k 0}+\sum_{i=1}^{4} C_{k i} x_{i}+\sum_{i=1}^{4} C_{k i i} x_{i}^{2}+\sum_{i<j=2}^{4} C_{k i j} x_{i} x_{j}
$$

where, $\mathrm{Y}$ is predicted response; $\mathrm{C}_{\mathrm{k} 0}, \mathrm{C}_{\mathrm{ki}}, \mathrm{C}_{\mathrm{kii}}$ and $\mathrm{C}_{\mathrm{kij}}$ are regression coefficients for intercept, linear effects, quadratic effects and double interactions, respectively; and $\mathrm{x}_{\mathrm{i}}$ and $x_{j}$ are coded values of the independent variables (Wu et al., 2012).

In order to evaluate the accuracy of the models, statistical analysis was carried out using ANOVA with p-value (Prob $\leq \mathrm{F}<0.0001$ ). Adequacy and predictability of the model were examined using lack of fit criterion, $\mathrm{R}^{2}$ linear regression coefficient of determination, adjusted $\mathrm{R}^{2}$, adequate precision and residual detection (Wu et al., 2012).

\section{Results and discussion}

\section{Characterization of graphene oxide nanosheets}

The FESEM images illustrate the morphology of graphene oxide nanosheets (Fig. 1). Morphology of the sheet structure of graphene oxide is clear in the images. The size of graphene oxide sheets is approximately $1-3 \mu \mathrm{m}$.

As can be seen in Figure 1, graphene oxide is semitransparent with some particles and lateral dimensions of several micrometer size and small holes, indicating the production accuracy of the synthesized graphene oxide sheets. FTIR spectra can be categorized into three classes: 2000-4000, 1300-2000 and $800-1300 \mathrm{~cm}^{-1}$. The first class is usually concerned with hydrogen bonded $\mathrm{O}-\mathrm{H}$; absorbed $\mathrm{H}_{2} \mathrm{O}$; mostly free $\mathrm{O}-\mathrm{H}$; symmetric, dehydration and aliphatic units; and asymmetric stretching vibrations in $\mathrm{CH}_{3}, \mathrm{CH}_{2}$ or $\mathrm{C}-\mathrm{H}$, bonds. The second class includes the most significant oxygen functionalities characterized by $\mathrm{N}-\mathrm{O}$ and $\mathrm{C}-\mathrm{O}$-containing structures. The third class is normally related to various $\mathrm{C}-\mathrm{O}$ bonds such as those in phenols, hydroxyl groups and ethers (Omar and Moloukhia, 2008). FTIR spectra of graphene oxide nanosheets are indicated in Figure 2. For graphene oxide, IR band in the range of $1032 \mathrm{~cm}^{-1}$ is assigned to alkoxy $\mathrm{C}-\mathrm{O}$ groups situated at the edges of the GO nanosheets. In the ranges of 1384 
and $1623 \mathrm{~cm}^{-1}$, it is concerned with carboxyl $\mathrm{C}-\mathrm{O}$ groups and $\mathrm{C}=\mathrm{C}$ in stretching vibrations of aromatic structures, respectively. In the ranges of 1694, 2921, and $3422 \mathrm{~cm}^{-1}$, IR band is assigned to stretching $\mathrm{CH}^{2}$, SP of $\mathrm{GO}$ aromatic sheets and $\mathrm{OH}$ groups of GO, respectively.

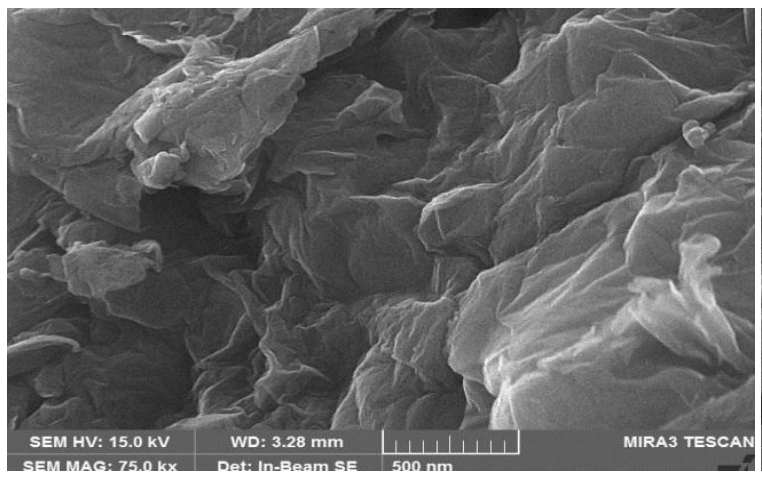

a

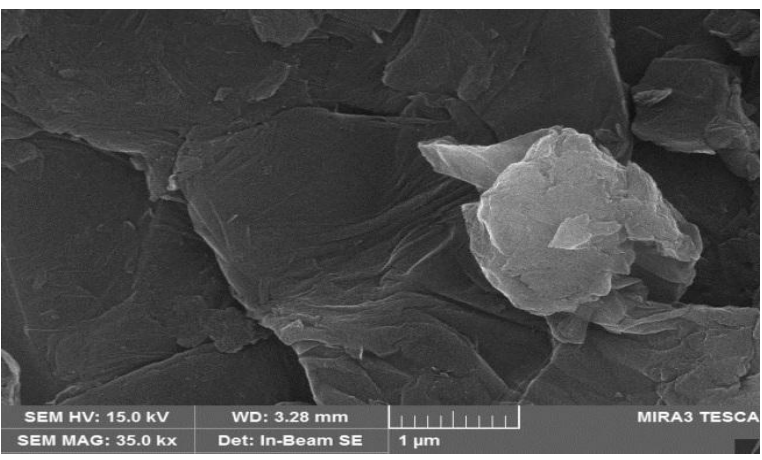

c

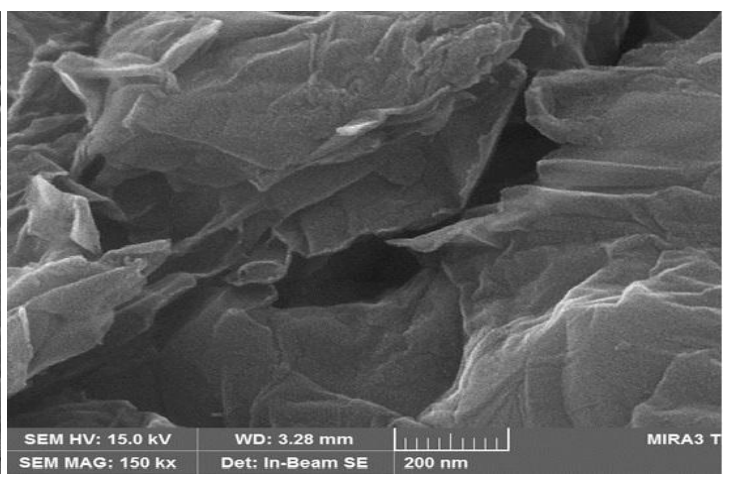

b

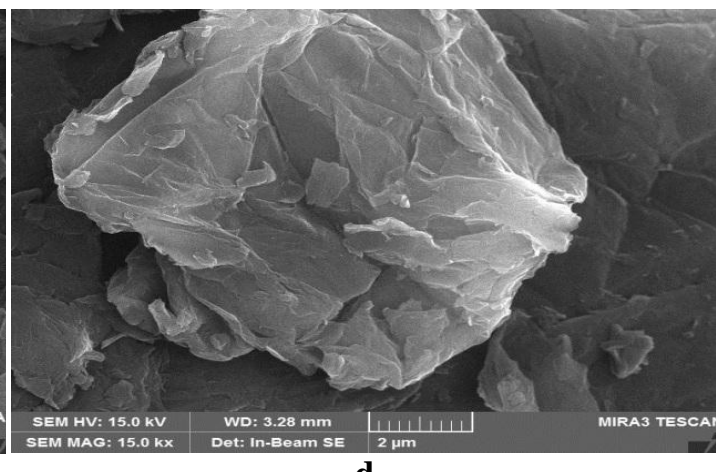

d

Figure 1. FESEM image of the graphene oxide: a) $200 \mathrm{~nm}$, b) $500 \mathrm{~nm}$, c) $1 \mu \mathrm{m}$, and d) $2 \mu \mathrm{m}$

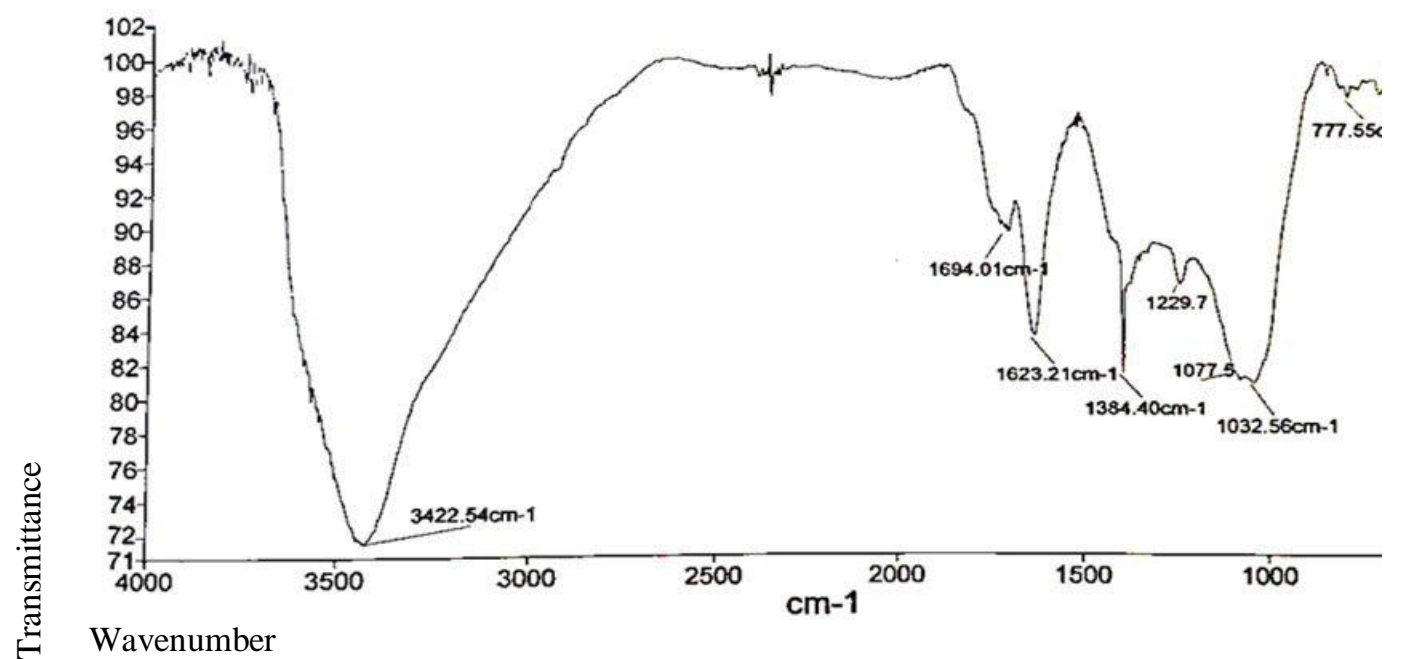

Figure 2. FTIR spectra of the synthesized graphene oxide

Figure 3 shows the XRD spectra of GO nanosheets. It is obvious that the synthesized adsorbent has only one intense peak centered at $11.3^{\circ}$. 


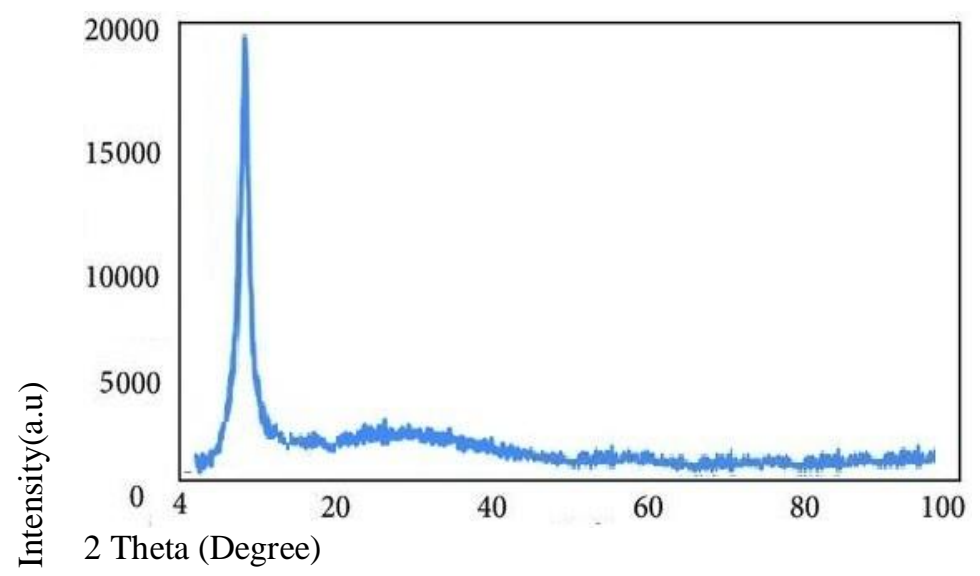

Figure 3. XRD spectra of the synthesized GO

\section{Statistical analysis}

The model and the quadratic equation were obtained using the Box-Behnken design. The maximum adsorption capacity of each experiment was finally recorded after adding the specified amounts of graphene oxide; adjusting the $\mathrm{pH}$, concentration and time; and conducting the experiments. In order to examine the heavy metals removal, it is necessary to analyze the input data, output parameters, and optimized values.

The statistical significance of the variables was evaluated by analysis of variance (ANOVA) (Tables 1C, $2 \mathrm{C}$ and 3C). The F-value implies that the terms in the model have a significant effect on the response. The p-value $(<0.0001)$ indicates that the terms are significant at the probability level of $95 \%$ (Tables $1 A, 2 A$ and $3 A$ ). The p-value of lack of fit (LOF) was not significant compared to the pure error, suggesting that the model fitted well with the experimental data. Adequate precision gives the ratio of signal to noise. The ratios greater than 4 are desirable. The predicted $\mathrm{R}^{2}$ was in reasonable agreement with the adjusted $\mathrm{R}^{2}$, which confirm the accuracy of the model (Hu et al., 2013; Tripathi et al., 2009). Software package of Design-Expert 10 version (Minneapolis, USA) was employed to design the experiments and analyze the obtained data.

\section{Cadmium $\left(\mathrm{Cd}^{2+}\right)$}

The following quadratic model was obtained using BBD and indicates the mathematical relation among the variables involved in $\mathrm{Cd}^{2+}(E q .5)$ :

$$
\begin{aligned}
Q e= & -(16.83)+(2.28 \times \mathrm{pH})+(0.36 \times \text { Conc })+(0.35 \times \text { Time })-(0.022 \times \mathrm{pH} \times \text { Conc })(\text { Eq. } 5) \\
& +(7.153 \times \mathrm{pH} \times \text { Time })+\left(0.709 \times \mathrm{pH}^{2} \mathrm{Conc}^{2}\right)-\left(5.85 \times \text { Time }^{2}\right)
\end{aligned}
$$

Plus signs preceding the parameters represent the synergistic effect of the variable, and minus signs indicate a reduction or reverse effect. When the value of one variable increases due to the rise in that of another variable, a positive correlation coefficient is formed, which represents the synergistic effect. On the contrary, when the value of a variable increases due to the reduction in that of another variable, the correlation coefficient is negative (Talib et al., 2017). Considering the parameters and statistical analysis of the model, the $R^{2}$ linear regression coefficient value is high $\left(R^{2}=0.9999\right)$ 
and it reasonably agrees with the adjusted $\mathrm{R}^{2}$ value of 0.9999 . Consequently, the quadratic model fits the experimental data within the range of operating factors. As the value of $\mathrm{R}^{2}$ is closer to 1 , power of the model will be greater in describing the response variations as a function of independent variables (Zarei et al., 2015). The significance of the predicted model is represented by the $F$ value which equals 16712 for adsorption of $\mathrm{Cd}^{2+}$ by the synthesized graphene oxide. The F-value of the model was found to be significant. The value of adequate precision represents the difference between the value of the predicted response and the average value of the prediction error. If this proportion reaches $>4$, it will be indicative of adequate signal in the model. According to the results, the mentioned value is 485 for $\mathrm{Cd}^{2+}$ adsorption.

Table 1. Initial factors and values obtained for $\mathrm{Cd}^{2+}$

\begin{tabular}{|c|c|c|c|c|}
\hline \multicolumn{5}{|c|}{ A) Independent variables and their levels } \\
\hline \multirow{2}{*}{ Variables } & \multirow{2}{*}{ Factor } & \multirow{2}{*}{ Unit } & \multicolumn{2}{|c|}{ Levels } \\
\hline & & & -1 & +1 \\
\hline $\mathrm{pH}$ & $\mathrm{pH}$ & \multirow{3}{*}{$\begin{array}{c}- \\
\mathrm{mg} / \mathrm{L} \\
\mathrm{min} .\end{array}$} & 2 & \multirow{2}{*}{$\begin{array}{c}6 \\
100\end{array}$} \\
\hline Conc. & Cd Conc. & & \multirow{2}{*}{$\begin{array}{c}10 \\
5\end{array}$} & \\
\hline Time & Time & & & 60 \\
\hline \multicolumn{5}{|c|}{ B) RSM design and the observed values } \\
\hline \multirow{2}{*}{ Run } & \multicolumn{3}{|c|}{ Factor } & \multirow{2}{*}{ Qe } \\
\hline & pH & Cd Conc. & Time & \\
\hline 1 & 6 & $\begin{array}{l}55 \\
55\end{array}$ & 5 & 41.7895 \\
\hline 2 & 4 & 55 & 32.5 & 29.8021 \\
\hline 3 & 4 & 10 & 60 & 8.40417 \\
\hline 4 & 6 & 10 & 32.5 & 31.653 \\
\hline 5 & 6 & 100 & 32.5 & 68.349 \\
\hline 6 & 4 & 55 & 32.5 & 29.8015 \\
\hline 7 & 4 & 55 & 32.5 & 30.839 \\
\hline 8 & 2 & 55 & 5 & 14.5829 \\
\hline 9 & 4 & 55 & 32.5 & 30.1014 \\
\hline 10 & 2 & 10 & 32.5 & 14.4269 \\
\hline 11 & 4 & 100 & 60 & 49.4414 \\
\hline 12 & 4 & 55 & 32.5 & 29.7955 \\
\hline 13 & 2 & 55 & 60 & 14.0758 \\
\hline 14 & 4 & 100 & 5 & 48.9891 \\
\hline 15 & 4 & 10 & 5 & 8.31452 \\
\hline 16 & 2 & 100 & 32.5 & 44.51 \\
\hline 17 & 6 & 55 & 60 & 42.8255 \\
\hline
\end{tabular}

Central point: $\mathrm{pH}=4$, Conc $=55$, Time $=32.5$ Average $=31.63$

C) Analysis of variance for RSM

\begin{tabular}{c|c|c|c|c|c}
\hline Factor & $\mathbf{S S}^{\mathbf{a}}$ & $\mathbf{d F}^{\mathbf{b}}$ & $\mathbf{M S}^{\mathbf{c}}$ & $\mathbf{F}$-value & p-value \\
\hline Model & 5021.51 & 8 & 627.69 & 16712.29 & $<0.0001$ \\
pH & 1544.50 & 1 & 1544.66 & 41122.58 & $<0.0001$ \\
Conc. & 3304.98 & 1 & 3304.98 & 87995.61 & $<0.0001$
\end{tabular}




\begin{tabular}{|c|c|c|c|c|c|}
\hline Time & 0.15 & 1 & 0.15 & 4.04 & 0.00794 \\
\hline $\mathrm{pH}^{*}$ conc & 16.52 & 1 & 16.52 & 439.76 & $<0.0001$ \\
\hline Conc* time & 0.62 & 1 & 0.62 & 16.48 & 0.0036 \\
\hline $\mathrm{pH}^{2}$ & 33.83 & 1 & 33.83 & 900.86 & $<0.0001$ \\
\hline Conc. $^{2}$ & 45.79 & 1 & 45.79 & 1219.44 & $<0.0001$ \\
\hline Time $^{2}$ & 82.53 & 1 & 82.53 & 2197.44 & $<0.0001$ \\
\hline Residual & 0.03 & 8 & 0.038 & & \\
\hline Lack fit & 0.02 & 4 & 0.049 & 1.91 & 0.2727 \\
\hline Pure error & 0.01 & 4 & 0.026 & & \\
\hline
\end{tabular}

\section{$\operatorname{Lead}\left(\mathrm{Pb}^{2+}\right)$}

Equation 6 indicates the mathematical relations among the input parameters of lead.

$$
\begin{aligned}
Q e= & -(10975639)+(37.36219 \times \mathrm{pH})+(0.90729 \times \text { Conc })+(1.61406 \times \text { Time })-(0.051692 \times \mathrm{pH} \times \text { Conc }) \\
& -(0.072090 \times \mathrm{pH} \times \text { Time })-\left(1.98777 \times(\mathrm{pH})^{2}\right)-\left(0.20492 \times(\text { Time })^{2}\right)
\end{aligned}
$$

The linear regression coefficient $R^{2}$ value (0.9999) and adjusted $R^{2}$ showed the effective removal of $\mathrm{Pb}^{2+}$ by graphene oxide and significance of the model for this metal with $\mathrm{F}=8141$. The obtained adequate precision is 313 .

\begin{tabular}{|c|c|c|c|c|c|}
\hline \multicolumn{6}{|c|}{ A) Independent variables and their levels } \\
\hline \multirow{2}{*}{ Variables } & \multirow{2}{*}{ Factor } & \multirow{2}{*}{ Unit } & \multicolumn{3}{|c|}{ Levels } \\
\hline & & & -1 & $\mathbf{0}$ & +1 \\
\hline $\mathrm{pH}$ & $\mathrm{pH}$ & - & 2 & 4 & 6 \\
\hline Conc. & $\mathrm{Pb}$ Conc. & $\mathrm{mg} / \mathrm{L}$ & 50 & 100 & 150 \\
\hline Time & Time & $\min$ & 5 & 32.5 & 60 \\
\hline \multicolumn{6}{|c|}{ B) RSM design and the observed values } \\
\hline \multirow{2}{*}{ Run } & \multicolumn{3}{|c|}{ Factor } & \multirow{2}{*}{\multicolumn{2}{|c|}{ Qe }} \\
\hline & pH & Pb Conc. & Time & & \\
\hline 1 & 2 & 100 & 5 & \multicolumn{2}{|c|}{44.4753} \\
\hline 2 & 4 & 100 & 32.5 & \multicolumn{2}{|c|}{99.8557} \\
\hline 3 & 4 & 100 & 32.5 & \multicolumn{2}{|c|}{99.1589} \\
\hline 4 & 4 & 100 & 32.5 & \multicolumn{2}{|c|}{99.5009} \\
\hline 5 & 6 & 100 & 5 & \multicolumn{2}{|c|}{99.0929} \\
\hline 6 & 4 & 150 & 60 & \multicolumn{2}{|c|}{118.551} \\
\hline 7 & 6 & 150 & 32.5 & \multicolumn{2}{|c|}{149.553} \\
\hline 8 & 4 & 100 & 32.5 & \multicolumn{2}{|c|}{98.8449} \\
\hline 9 & 6 & 100 & 60 & \multicolumn{2}{|c|}{99.3135} \\
\hline
\end{tabular}

Table 2. Initial factors and values obtained $P b^{2+}$ 


\begin{tabular}{l|l|c|c|c}
10 & 4 & 50 & 5 & 48.7973 \\
11 & 2 & 150 & 32.5 & 103.863 \\
12 & 2 & 100 & 60 & 51.6843 \\
13 & 6 & 50 & 60.5 & 49.5921 \\
14 & 4 & 50 & 32.5 & 49.4307 \\
15 & 4 & 100 & 32.5 & 99.2496 \\
16 & 2 & 50 & 5 & 23.1052 \\
17 & 4 & 150 & 112.356 \\
\hline
\end{tabular}

Central point: $\mathrm{pH}=4$, Conc $=100$, Time $=32.5$ Average $=85.09$

\begin{tabular}{|c|c|c|c|c|c|}
\hline \multicolumn{6}{|c|}{ C) Analysis of variance for RSM } \\
\hline Factor & $\mathbf{S S}^{\mathrm{a}}$ & $\mathbf{d F}^{\mathbf{b}}$ & $\mathbf{M S}^{\mathrm{c}}$ & F-value & p-value \\
\hline Model & 16032.24 & 7 & 2290.32 & 8141.96 & $<0.0001$ \\
\hline $\mathrm{pH}$ & 2075.12 & 1 & 2075.12 & 7376.94 & $<0.0001$ \\
\hline Conc. & 4492.39 & 1 & 4492.39 & 15970.21 & $<0.0001$ \\
\hline Time & 0.11 & 1 & 0.11 & 0.39 & 0.5545 \\
\hline $\mathrm{pH}^{*}$ conc & 45.86 & 1 & 45.86 & 163.02 & $<0.0001$ \\
\hline $\mathrm{pH}^{*}$ time & 26.98 & 1 & 26.98 & 95.91 & $<0.0001$ \\
\hline $\mathrm{pH}^{2}$ & 120.86 & 1 & 120.86 & 429.66 & $<0.0001$ \\
\hline Time $^{2}$ & 589.09 & 1 & 589.09 & 2094.20 & $<0.0001$ \\
\hline Residual & 1.69 & 6 & 0.28 & & \\
\hline Lack fit & 1.11 & 2 & 0.56 & 3.86 & 0.1146 \\
\hline Pure error & 0.058 & 4 & 0.14 & & \\
\hline Core total & 16033.93 & 17 & & & \\
\hline
\end{tabular}

$\mathrm{R}^{2}=0.9999$, Adj. $\mathrm{R}^{2}=0.9998$, Adeq. precision $=313.3$

${ }^{\mathrm{a}} \mathrm{Sum}$ of square

${ }^{\mathrm{b}}$ Degree of freedom

${ }^{\mathrm{c}}$ Mean square

\section{Chromium (Cr(III))}

Equation 7 indicates the mathematical relations among the input parameters of chromium.

$$
\begin{aligned}
Q e= & (4.65520)+(0.68819 \times \mathrm{pH})-(0.18288 \times \text { Conc })-(0.098263 \times \text { Time }) \\
& +(0.11980 \times \mathrm{pH} \times \text { Conc })-\left(5.56740 \times(\text { Conc })^{2}\right)+\left(1.52885 \times(\text { Time })^{2}\right)
\end{aligned}
$$

$\mathrm{R}^{2}$ value (0.9980) and adjusted $\mathrm{R}^{2}$ suggest good removal of Cr(III) by graphene oxide and significance of the model for this metal with $\mathrm{F}=655$. The obtained adequate precision is 90 . 
Table 3. Initial factors and values obtained for Cr(III)

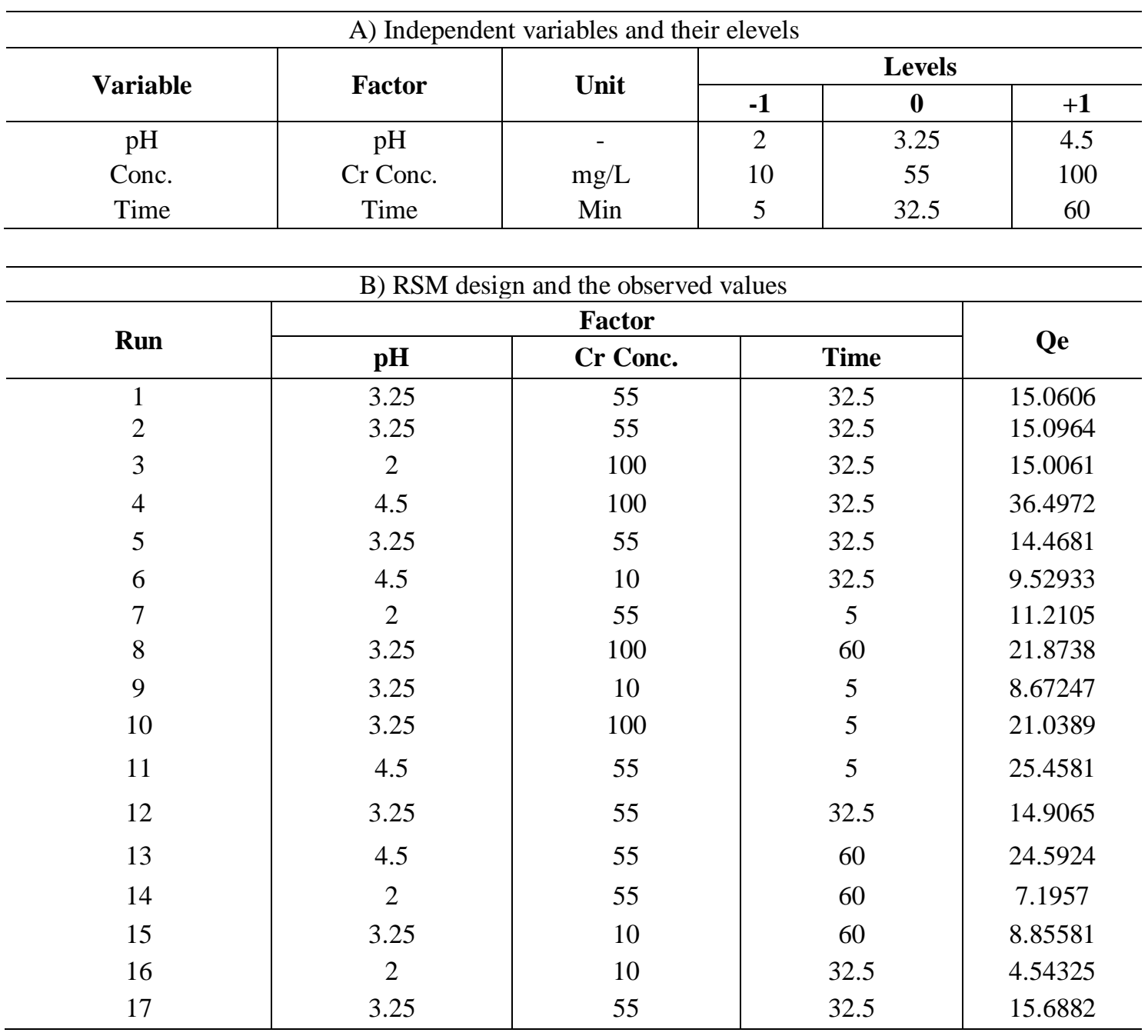

Central point: $\mathrm{pH}=3.25$, Conc $=55$, Time $=32.5$

\begin{tabular}{c|c|c|c|c|c}
\hline \multicolumn{7}{c}{ C) Analysis of variance for RSM } \\
\hline Factor & $\mathbf{S S}^{\mathbf{a}}$ & $\mathbf{d F}^{\mathbf{b}}$ & $\mathbf{M S}^{\mathbf{c}}$ & F-value & p-value \\
\hline Model & 1000.19 & 6 & 166.70 & 655.0 & $<0.0001$ \\
$\mathrm{pH}$ & 386.27 & 1 & 386.27 & 1517.76 & $<0.0001$ \\
Conc. & 243.34 & 1 & 243.34 & 956.15 & $<0.0001$ \\
Time & $6.104 \mathrm{e}$ & 1 & $6.104 \mathrm{e}$ & 0.024 & 0.8808 \\
pH* conc. $^{*}$ & 100.49 & 1 & 100.49 & 394.83 & $<0.0001$ \\
Conc. $^{2}$ & 4.13 & 1 & 4.13 & 16.24 & 0.0038 \\
Time $^{2}$ & 4.41 & 1 & 4.41 & 17.35 & 0.0031 \\
Residual & 2.04 & 8 & 0.25 & & 0.3199 \\
Lack fit & 1.27 & 4 & 0.32 & 1.65 & \\
Pure error & 0.77 & 4 & 0.19 & & \\
\hline
\end{tabular}

$\mathrm{R}^{2}=0.9980$, Adj. $\mathrm{R}^{2}=0.9964$, Adeq. precision $=90.17$

${ }^{\mathrm{a}} \mathrm{Sum}$ of square

${ }^{\mathrm{b}}$ Degree of freedom

${ }^{\mathrm{c}}$ Mean square 


\section{Comparative effects of the studied variables on removal efficiency}

Figure 4 shows the effect of all the three variables on the removal rate at a point and the response level is visible and comparable in the designing method. Removal efficiency increased with the increase of $\mathrm{pH}$ (a) and concentration (b). However, increase in the contact time (c) did not have a significant effect on the value obtained for the heavy metals removal, and a different result was obtained for each metal.

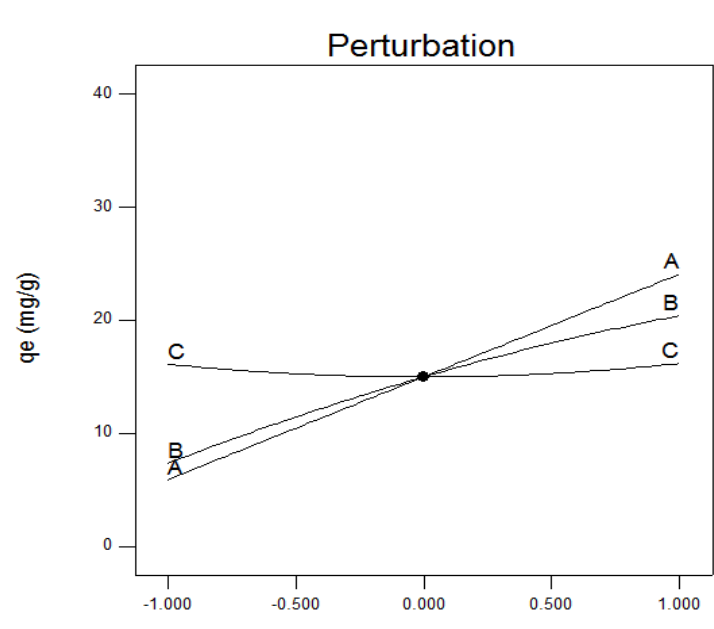

Deviation from reference point (coded units)

$\mathbf{a}$

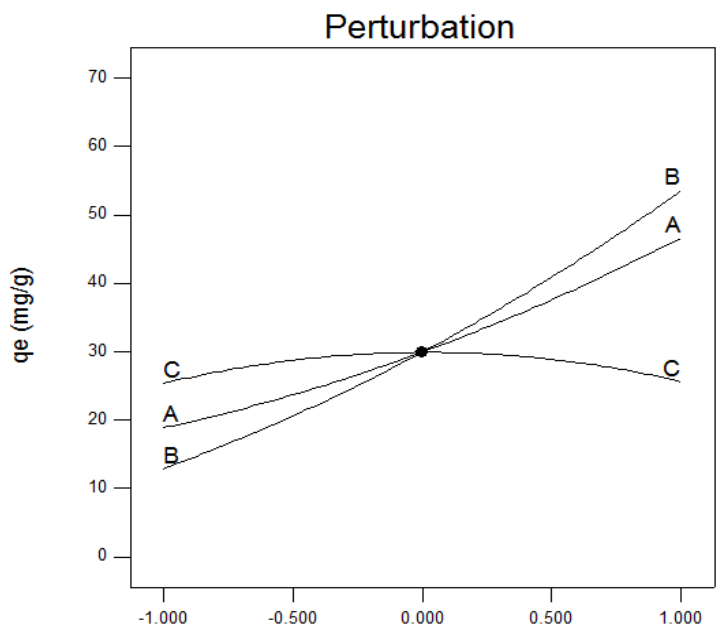

Deviation from reference point (coded units)

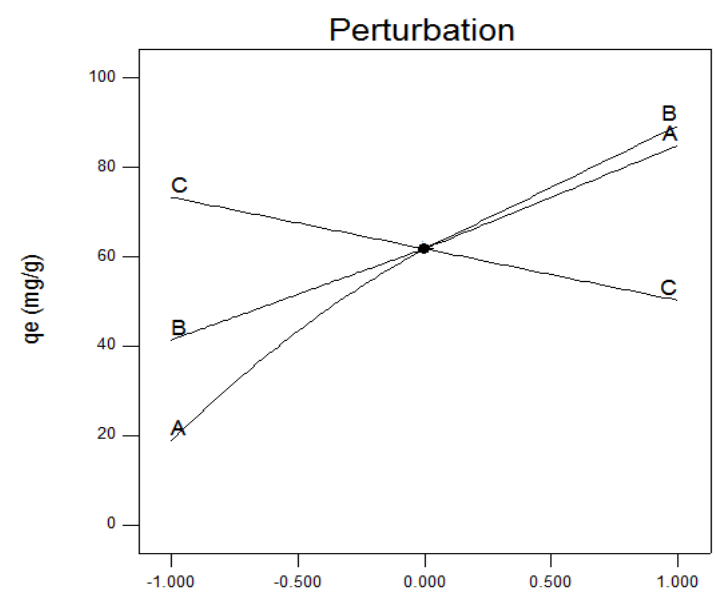

Deviation from reference point (coded units)

c

Figure 4. Perturbation plots of removal by graphene oxide: a) chromium, b) cadmium, c) lead

\section{Effect of the variables on responses}

\section{Effect of $p H$}

$\mathrm{pH}$ is a determinant factor in adsorption of $\mathrm{Cr}(\mathrm{III}), \mathrm{Cd}^{2+}$ and $\mathrm{Pb}^{2+}$ ions from aqueous solutions ( $\mathrm{Li}$ and Wang, 2009; Ramkumar et al., 2008). To study the effect of $\mathrm{pH}$ on adsorption capacity of graphene oxide, $\mathrm{pH}$ of the solution was tested in the ranges of 26 for $\mathrm{Cd}^{2+}$ and $\mathrm{Pb}^{2+}$ and 2-4.5 for $\mathrm{Cr}$ (III). Adsorption capacity with contaminant concentration and also the contact time versus $\mathrm{pH}$ are illustrated in Figure 5. The value 
of $\mathrm{pH}_{\mathrm{PZC}}$ for synthesized graphene oxide was obtained as 3 . When $\mathrm{pH}$ of the solution is below 3 , the adsorbent surface is positively charged. Any increase in $\mathrm{pH}$ leads to change of surface charge from positive to negative. This demonstrates that heavy metals adsorption onto graphene oxide and thereby heavy metals removal are higher in $\mathrm{pH} \geq 3$ (Lingamdinne et al., 2008). Results showed that the removal of $\mathrm{Cr}(\mathrm{III}), \mathrm{Cd}^{2+}$ and $\mathrm{Pb}^{2}$ by graphene nanoparticles was affected by $\mathrm{pH}$ of the solution. In the adsorption process, two ions of $\mathrm{OH}^{-}$and $\mathrm{H}^{+}$are responsible for decomposition (Zarei et al., 2015). For chromium, by raising the initial $\mathrm{pH}$ of the solution from 2 to 4.5 , the adsorption capacity of graphene oxide increases from 4.5 to 36.5 on a constant trend. As can be seen in Figure $5 a$ and $b$, the maximum $\mathrm{Cr}$ (III) adsorption occurred at $\mathrm{pH}=4.5$. Analysis of Figure 5 indicates that the negatively charged groups on the adsorbent surface and ionization of binding sites in functional groups in the cell wall increase with the increase of $\mathrm{pH}$. Consequently, the removal of $\mathrm{Cr}(\mathrm{III})$ ion from aqueous solution and adsorption capacity were increased. Zhang et al. (2018) concluded that $\mathrm{pH}$ is the most effective variable in adsorbing chromium, and changes in $\mathrm{pH}$ may have a marked effect on kinetic characteristics and adsorption equilibrium. They studied the $\mathrm{pH}$ range of 2-11 and demonstrated that the highest adsorption capacity of chromium occurred at the $\mathrm{pH}$ range of 3-5 and subsequently the adsorption capacity considerably increased with the increase of pH. Another study was conducted by Jiang et al. (2017) on the effective synthesis of graphite compounds for the effective removal of chromium from aqueous solutions. The mentioned study was carried out in the $\mathrm{pH}$ range of $1-9$, the initial concentrations of $10-100 \mathrm{mg} / \mathrm{L}$ and time duration of 5 to $300 \mathrm{~min}$. The best result was achieved at $\mathrm{pH}$ range of 4-6 and concentration of $100 \mathrm{mg} / \mathrm{L}$. By increasing the time from 5 to $180 \mathrm{~min}$, initially the adsorption efficiency increased rapidly and then reached the saturation point (Jiang et al., 2017). According to Figure $5 c$ and $d$, the effects of variables on $\mathrm{Cd}^{2+}$ adsorption indicate that with the increase of initial $\mathrm{pH}$ from 2 to 6 , the graphene oxide adsorption capacity increases from 0.2 to $32.2 \mathrm{mg} / \mathrm{g}$. At the first stage, adsorption capacity rapidly increases with the increase of $\mathrm{pH}$ from 2 to 4.5. Afterwards, with the increase of $\mathrm{pH}$ from 4.5 to 6 , the slope of curve constantly increases and the maximum adsorption capacity for $\mathrm{Cd}^{2+}$ occurs at $\mathrm{pH}=6$. According to the tested conditions, cadmium, lead and chromium began to precipitate at $\mathrm{pH}$ values greater than 6 and 4.5. Similar results have been reported in other studies, confirming that cadmium and lead begin to precipitate at $\mathrm{pH}$ values greater than 6 (Zhao et al., 2011). A study conducted by Sitko et al. (2013) on adsorption of metal ions using graphene oxide revealed that when $\mathrm{pH}$ increase from 3 to $4, \mathrm{Cd}^{2+}$ adsorption capacity rapidly increases and becomes constant at pH range of 5-8 (Depci et al., 2012; Zhao et al., 2011). The effects of variables on $\mathrm{Pb}^{2+}$ ion are shown in Figure 5c. Adsorption increases from 23 to $89.9 \mathrm{mg} / \mathrm{g}$ with the increase of initial $\mathrm{pH}$ from 2 to 6 . At the first step, the adsorption capacity increases quickly with the increase of $\mathrm{pH}$ from 2 to 4 . Afterwards the adsorption capacity increases with a slight slope with the increase of $\mathrm{pH}$ from 4 to 6 . According to the results obtained in other studies, $\mathrm{Cr}$ (III) and $\mathrm{Pb}^{2+}$ adsorptions rapidly increase at the $\mathrm{pH}$ range of 2-3, and then the increasing rate slows down (Lingamdinne et al., 2016; Hao et al., 2012). Other studies have shown that most of the $\mathrm{Cd}^{2+}$ and $\mathrm{Pb}^{2+}$ adsorption processes take place at the $\mathrm{pH}$ range of 5.3 to 6 , and $\mathrm{Cr}(\mathrm{III}), \mathrm{Cd}^{2+}$ and $\mathrm{Pb}^{2+}$ ions start to precipitate at the pH values higher than 6 (Fan et al., 2012; Jafari et al., 2016). As a result, the maximum rate of $\mathrm{Pb}^{2+}$ and $\mathrm{Cd}^{2+}$ adsorption occurs at $\mathrm{pH}=5.5$ and the maximum rate of $\mathrm{Cr}(\mathrm{III})$ adsorption occurs at $\mathrm{pH}=4.5$. Figure 5 indicates the 
effect of $\mathrm{pH}$ on time and concentration for $\mathrm{Cr}(\mathrm{III}), \mathrm{Cd}^{2+}$ and $\mathrm{Pb}^{2+}$ adsorptions in aqueous solutions.

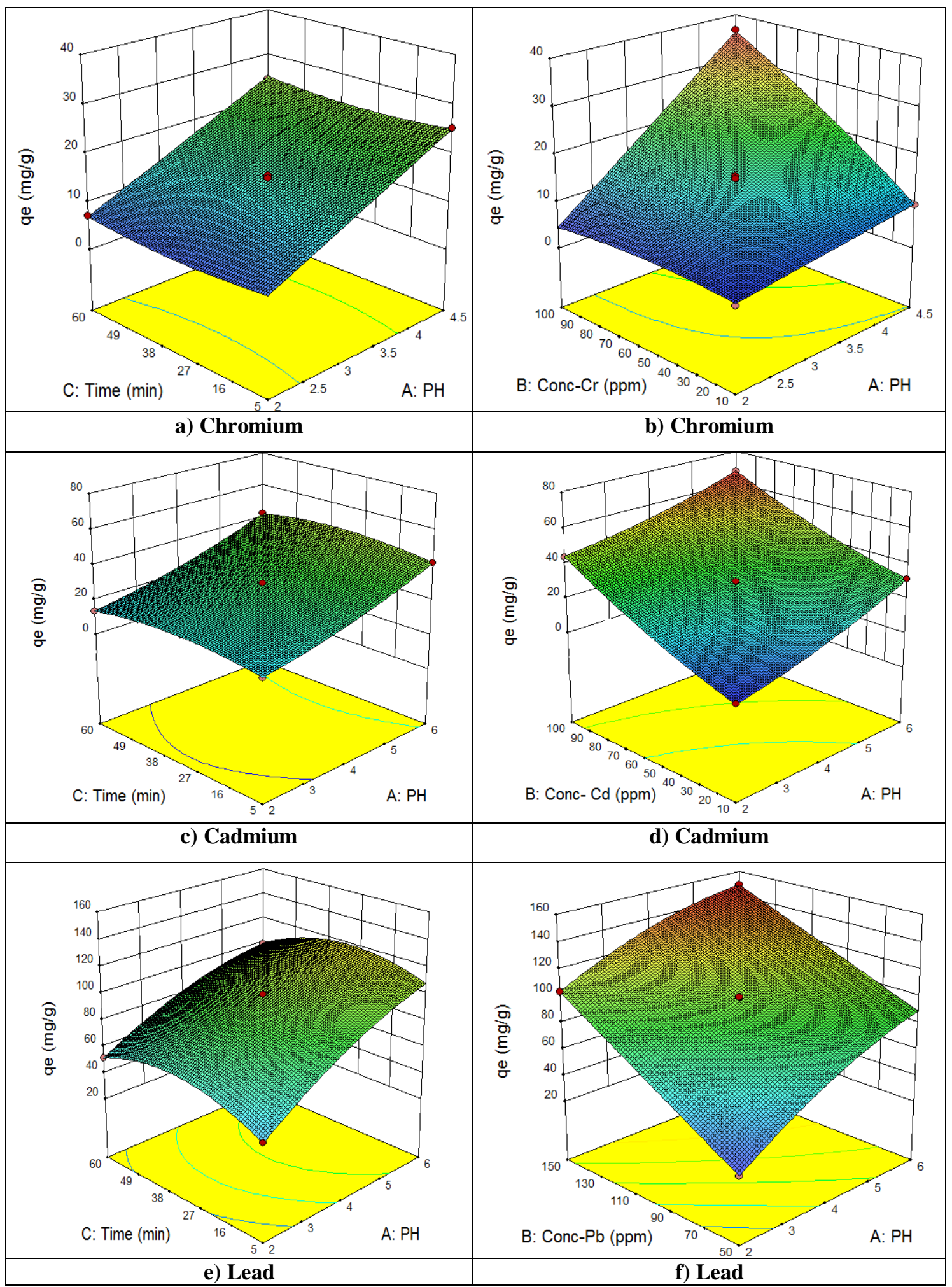

Figure 5. The $3 D$ response surface for $\mathrm{Cr}(\mathrm{III}):$ a) $\mathrm{pH}$ and time, b) $\mathrm{pH}$ and concentration; for $\mathrm{Cd}^{2+}:$ c) $\mathrm{pH}$ and time, d) $\mathrm{pH}$ and concentration; and for $\mathrm{Pb}^{2+}$ : e) $\mathrm{pH}$ and time, f) $\mathrm{pH}$ and concentration 


\section{Effects of initial concentration and contact time on adsorption capacity}

The effect of concentration on adsorption capacity in optimum conditions $\left(25{ }^{\circ} \mathrm{C}\right)$ shows that the adsorption capacity of graphene oxide increases smoothly from 63 to $135 \mathrm{mg} / \mathrm{g}$ for $\mathrm{Pb}^{2+}$ with the increase of initial concentration from 50 to $150 \mathrm{mg} / \mathrm{L}$. Also, with the increase of initial concentration of the solution from 10 to $100 \mathrm{mg} / \mathrm{L}$, graphene oxide adsorption capacity increases from 5 to $38 \mathrm{mg} / \mathrm{g}$ for $\mathrm{Cr}$ (III) and from 1.2 to $68 \mathrm{mg} / \mathrm{g}$ for $\mathrm{Cd}^{2+}$. As can be seen in Figure 5, the maximum adsorption rate took place at high concentrations. This can be due to the fact that increase of adsorbent concentration increases the area of adsorbent and facilitates the access to more adsorbed sites, thus increasing the rate of heavy metals absorption. Due to the large number of sites available for absorption and absorption equilibrium in the initial stage of absorption, the adsorption process progresses steadily (Vasudevan et al., 2011). At different initial concentrations of heavy metals, the adsorption intensity was initially constant; however, over time, minor changes happened, and finally, it reached a constant value. Reaching the equilibrium time, the amount of adsorbed ions did not noticeably change over time. According to surface plots, increase of contact time did not lead to a considerable change in adsorption efficiency. Many studies yet have been done about the effect of initial concentration and contact time of adsorbent on the removal of metal ions. In some studies it has been suggested that the optimum contact time to reach the equilibrium condition for the removal of metal ions is less than $60 \mathrm{~min}$ (Barassi et al., 2009; Ramana et al., 2012; Sari and Tuzen, 2009). After optimization, the best values for heavy metals were obtained at $\mathrm{pH}=6$ for $\mathrm{Pb}^{2+}$, and the maximum adsorption capacity of adsorbent reached $136 \mathrm{mg} / \mathrm{g}$ in initial concentration of $128 \mathrm{mg} / \mathrm{L}$ and contact time of $30 \mathrm{~min}$. However, for $\mathrm{Cd}^{2+}$ ion at $\mathrm{pH}=6$, the maximum adsorption capacity was $68 \mathrm{mg} / \mathrm{g}$ in initial concentration of $100 \mathrm{mg} / \mathrm{L}$ and contact time of $33 \mathrm{~min}$. Also, for $\mathrm{Cr}$ (III) at $\mathrm{pH}=4.5$, the maximum adsorption capacity was $37.63 \mathrm{mg} / \mathrm{g}$ initial concentration of $100 \mathrm{mg} / \mathrm{L}$ and contact time of $6 \mathrm{~min}$. In a similar study, the maximum graphene adsorption capacity for lead was found to be $120 \mathrm{mg} / \mathrm{g}$ at $\mathrm{pH}=5$ and contact time of 30 min (Vasudevan and Lakshmi, 2012). Also, in another study, the maximum adsorption capacity for lead was obtained as $101 \mathrm{mg} / \mathrm{g}$ at $\mathrm{pH}=6$ (Awad et al., 2017). In a study conducted by Sitko et al. (2013) on cadmium, the maximum adsorption capacity was $49 \mathrm{mg} / \mathrm{g}$ at $\mathrm{pH}=5$ and contact time of $120 \mathrm{~min}$. In another study, the maximum graphene oxide adsorption capacity for cadmium $(88 \mathrm{mg} / \mathrm{g})$ was obtained in initial concentration of $30 \mathrm{mg} / \mathrm{L}$ and a contact time of $30 \mathrm{~min}$ (Sheet et al., 2014). In this study, the values obtained as the maximum graphene adsorption capacity for $\mathrm{Cr}(\mathrm{III}), \mathrm{Cd}^{2+}$ and $\mathrm{Pb}^{2+}$ were consistent with the findings reported in other studies.

\section{Examination of adsorption isotherms}

Isotherm is the most important parameter in the design of adsorption systems. It represents the relation between the adsorption capacity of an adsorbent and the adsorbate concentration. The Langmuir and Freundlich adsorption isotherm models are used in this study. Langmuir isotherm is based on monolayer adsorption and homogeneity of the adsorbate with equal energy on the whole surface of the adsorbent. Contrary to Langmuir isotherm, Freundlich isotherm is on the basis of multilayer adsorption and heterogeneity of the adsorbate on the adsorbent (Jamali et al., 2015). The results of adsorption experiments with different $\mathrm{pH}$ values, contact times and initial concentrations of heavy metals have been analyzed using Langmuir and Freundlich 
models. The values of adsorption isotherms are obtained using the equations presented in Table 4.

Table 4. Linear equations and isotherm parameters

\begin{tabular}{|c|c|c|}
\hline \multicolumn{2}{|c|}{ Model } & Parameters \\
\hline Jethor & & $\frac{C_{e}}{q_{e}}=\frac{1}{Q^{\circ} b}+\frac{C_{e}}{Q^{\circ}}$ \\
\hline & & $\log \left(q_{e}\right)=\log \left(K_{f}\right)+\frac{1}{n} \log \left(C_{e}\right)$ \\
\hline
\end{tabular}

In Langmuir and Freundlich equations, $\mathrm{C}_{\mathrm{e}}$ represents equilibrium concentration of heavy metals in $\mathrm{mg} / \mathrm{L}$; $\mathrm{q}_{\mathrm{e}}$ indicates the amount of heavy metals adsorbed in equilibrium time in $\mathrm{mg} / \mathrm{g} ; \mathrm{Q}^{\circ}$ and $\mathrm{b}$ are Langmuir parameters related to the maximum absorption capacity and the energy of absorption correlation, respectively; and $\mathrm{K}_{\mathrm{f}}$ and $\mathrm{n}$ are Freundlich constants which represent adsorption capacity and desirability of adsorption process, respectively. Values of $\mathrm{K}_{\mathrm{f}}$ and $\mathrm{n}$ parameters are, respectively, determined through intercept and linear regression slope of $\log \left(\mathrm{C}_{\mathrm{e}}\right)$ versus $\log \left(\mathrm{q}_{\mathrm{e}}\right)$. In this model, $\mathrm{n}$ values less than 1 indicate weak adsorption. The values between 1-2 and 2-10 represent difficult and desired adsorption, respectively (Jamali et al., 2015).

Referring to Table 5, " $\mathrm{n}$ " constant values of 1.9 for $\mathrm{Cd}^{2+}$ and $\mathrm{Cr}$ (III) and 7.4 for $\mathrm{Pb}^{2+}$ show the higher fitness of Freundlich model for $\mathrm{Pb}^{2+} \cdot \mathrm{R}^{2}$ values for $\mathrm{Cd}^{2+}$ and $\mathrm{Cr}$ (III) obtained from Langmuir isotherm are greater than those obtained from Freundlich model, indicating the higher fitness of Langmuir isotherm for $\mathrm{Cd}^{2+}$ and $\mathrm{Cr}$ (III). However, Freundlich model has a higher fitness for $\mathrm{Pb}^{2+}$ ion (Fig. 6). Surface adsorption of $\mathrm{Pb}^{2+}$ ions takes place onto the monolayer of the adsorbent surface. Adsorption sites are equally and similarly present on the surface area of the adsorbent (Iram et al., 2010).

Table 5. Values of adsorption isotherm models

\begin{tabular}{c|c|c|c|c|c|c}
\hline \multirow{2}{*}{ Heavy metals } & \multicolumn{3}{|c|}{ Langmuir model } & \multicolumn{3}{c}{ Freundlich model } \\
\cline { 2 - 7 } & $\mathbf{R}^{\mathbf{2}}$ & $\mathbf{b}(\mathbf{L} / \mathbf{m g})$ & $\mathbf{q}_{\max }(\mathbf{m g} / \mathbf{g})$ & $\mathbf{R}^{\mathbf{2}}$ & $\mathbf{N}$ & $\begin{array}{c}\mathbf{K}(\mathbf{m g} / \mathbf{g}) \\
(\mathbf{L} / \mathbf{m g})\end{array}$ \\
\hline $\mathrm{Cr}(\mathrm{III})$ & 0.985 & 21.32 & 41.32 & 0.928 & 1.94 & 22.84 \\
$\mathrm{~Pb}^{2+}$ & 0.072 & 0.031 & 833.33 & 0.958 & 7.42 & 24.46 \\
$\mathrm{Cd}^{2+}$ & 0.997 & 0.264 & 87.71 & 0.958 & 1.94 & 18.23 \\
\hline
\end{tabular}

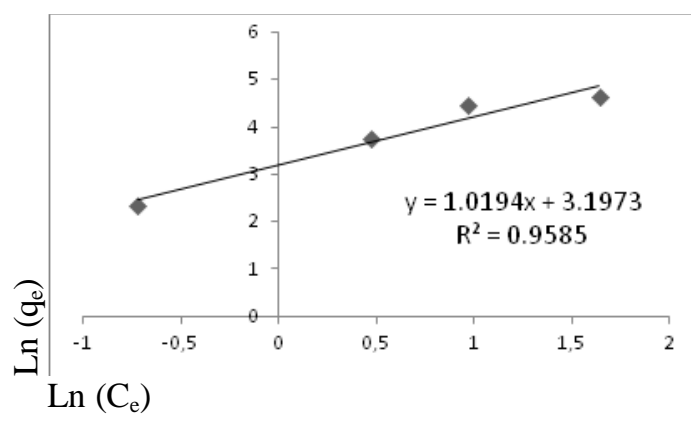

$\mathbf{a}$

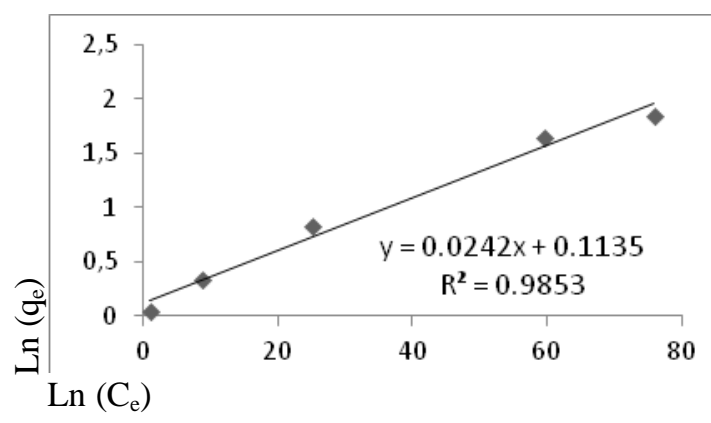

b 


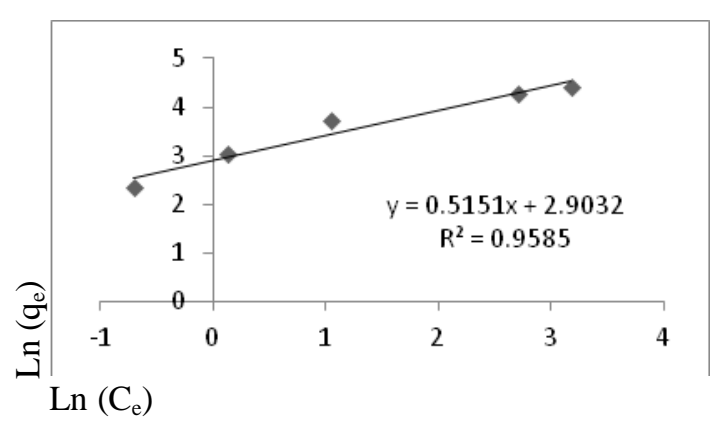

c

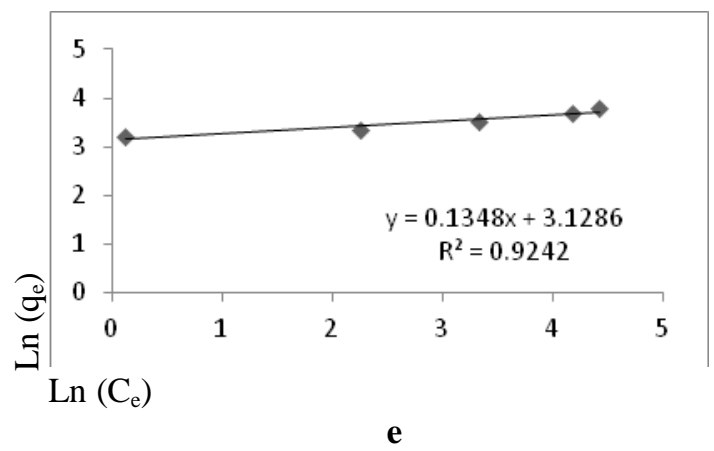

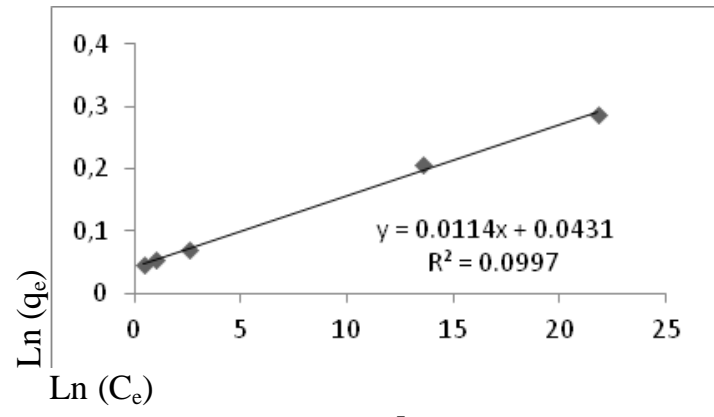

d

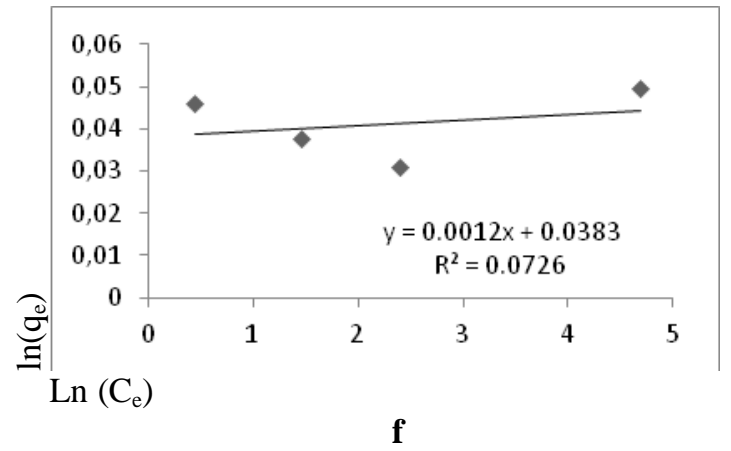

Figure 6. Adsorption isotherm of graphene oxide: a) Freundlich Cr(III), b) Langmuir Cr(III), c) Freundlich $\mathrm{Cd}^{2+}$, d) Langmuir $\mathrm{Cd}^{2+}$, e) Freundlich $\mathrm{Pb}^{2+}$ ion, and f) Langmuir $\mathrm{Pb}^{2+}$

\section{Conclusion}

In the present study, graphene oxide nanoparticles were used to examine the removal of $\mathrm{Cr}(\mathrm{III}), \mathrm{Cd}^{2+}$ and $\mathrm{Pb}^{2+}$ which were synthesized by Hummer's method. RSM was used according to the Box-Behnken design to evaluate the effect of independent variables on response function. Properties of the synthesized adsorbent were studied using FESEM, FTIR, and XRD. In FESEM images, the size of graphene oxide sheets was 1 to $3 \mu \mathrm{m}$ with wrinkled morphology. FTIR spectra were classified into three groups, and it was observed that ranges of alkoxy groups, carboxyl groups, stretching vibration of aromatic, stretching $\mathrm{CH}_{2}$, aromatic sheets and $\mathrm{OH}$ groups of graphene oxide sheets were in agreement with the results of previous studies. XRD spectra exhibited an intense peak at $2 \Theta=11.3^{\circ}$ for graphene oxide. Some of the effective parameters for the removal of $\mathrm{Cr}(\mathrm{III}), \mathrm{Cd}^{2+}$ and $\mathrm{Pb}^{2+}$ were optimized. After optimization, the maximum adsorption capacity of adsorbent reached $136 \mathrm{mg} / \mathrm{g}$ for $\mathrm{Pb}^{2+}$ at $\mathrm{pH}=6$, initial concentration of 128 $\mathrm{mg} / \mathrm{L}$ and contact time of $30 \mathrm{~min}$. However, the maximum adsorption capacity was 68 $\mathrm{mg} / \mathrm{g}$ for $\mathrm{Cd}^{2+}$ ion at $\mathrm{pH}=6$, initial concentration of $100 \mathrm{mg} / \mathrm{L}$ and contact time of 33 min. Also, the maximum adsorption capacity was $37.63 \mathrm{mg} / \mathrm{g}$ for $\mathrm{Cr}(\mathrm{III})$ at $\mathrm{pH}=4.5$, initial concentration of $100 \mathrm{mg} / \mathrm{L}$ and contact time of $6 \mathrm{~min}$. The high value of $\mathrm{R}^{2}$ linear regression coefficient was desirable. Values of $R^{2}$, adjusted coefficient (Adj. $R^{2}$ ) and predicted coefficient (Pred. $\mathrm{R}^{2}$ ) were acceptable. The high value of $\mathrm{R}^{2}$ linear regression coefficient guarantees the desirability of the presented quadratic equation and is representative of good fitness of the data with the predicted model. According to the results, all linear, quadratic and interaction effects of the variables were significant with a safety factor of $95 \%$, indicating the effect of the variables on $\mathrm{Cr}(\mathrm{III}), \mathrm{Cd}^{2+}$ and $\mathrm{Pb}^{2+}$ removal using graphene oxide adsorbents. Adequate precision indicated the noise ratio, and the values greater than 4 represented the desirability of the quadratic equation 
model for prediction. Replicability of the model, with C.V value of less than $10 \%$, indicated a good condition. Values obtained from Langmuir isotherm equation for $\mathrm{Cr}(\mathrm{III})$ and $\mathrm{Cd}^{2+}$ exhibit the maximum fitness of this model with $\mathrm{Cr}(\mathrm{III})$ and $\mathrm{Cd}^{2+}$. However, the values obtained from Freundlich isotherm for $\mathrm{Pb}^{2+}$ ions showed the maximum fitness of this isotherm with $\mathrm{Pb}^{2+}$ ions. The results showed that graphene oxide was effective in removing heavy metals from aqueous solutions. It was concluded that the adsorption process is a function of $\mathrm{pH}$ value, initial concentration of the solution and contact time, and graphene oxide can be effectively used to remove heavy metals from polluted waters. Finfings in this study can be applied in the treatment of industrial wastewater. Further studies should be carried out to investigate the efficiency of the proposed method for the removal of heavy metals at lower concentrations.

Acknowledgements. The authors wish to extend their gratitude to University of Tehran as well as the Islamic Azad University of Hamadan for providing the laboratory and the required experimental equipments.

Conflict of interests. The authors state that there is no conflict of interests regarding publication of this article.

\section{REFERENCES}

[1] Amarasinghe, B. M. W. P. K., Williams, R. A. (2007): Tea waste as a low cost adsorbent for the removal of $\mathrm{Cu}$ and $\mathrm{Pb}$ from wastewater. - Chemical Engineering Journal 132(1-3): 299-309.

[2] Awad, F., AbouZeid, K., El-Maaty, W., El-Wakil, A., El-Shall, M. (2017): Efficient removal of heavy metals from polluted water with High Selectivity for Mercury (II) by 2Imino-4-thiobiuret-partially reduced graphene oxide (IT-PRGO). - ACS Applied Materials \& Interfaces 9(39): 34230-34242.

[3] Barassi, G., Valdés, A., Araneda, C., Basualto, C., Sapag, J., Tapia, C., Valenzuela, F. (2009): Cr (VI) sorption behavior from aqueous solutions onto polymeric microcapsules containing a long-chain quaternary ammonium salt: kinetics and thermodynamics analysis. - Journal of Hazardous Materials 172(1): 262-268.

[4] Belay, A. A. (2010): Impacts of chromium from tannery effluent and evaluation of alternative treatment options. - Journal of Environmental Protection 1(01): 53.

[5] Chaiyakun, S., Witit-Anun, N., Nuntawong, N., Chindaudom, P., Oaew, S., Kedkeaw, C., Limsuwan, P. (2012): Preparation and characterization of graphene oxide nanosheets. Procedia Engineering 32: 759-764.

[6] Depci, T., Kul, A.R., Önal, Y. (2012): Competitive adsorption of lead and zinc from aqueous solution on activated carbon prepared from Van apple pulp: study in single-and multi-solute systems. - Chemical Engineering Journal 200: 224-236.

[7] Fan, L., Luo, C., Sun, M., Li, X., Qiu, H. (2013): Highly selective adsorption of lead ions by water-dispersible magnetic chitosan/graphene oxide composites. - Colloids and Surfaces B: Biointerfaces 103: 523-529.

[8] Fan, L., Luo, C., Sun, M., Qiu, H. (2012): Synthesis of graphene oxide decorated with magnetic cyclodextrin for fast chromium removal. - Journal of Materials Chemistry 22(47): 24577-24583.

[9] Fu, F., Wang, Q. (2011): Removal of heavy metal ions from wastewaters: a review. Journal of Environmental Management 92(3): 407-418.

[10] Ghafari, S., Aziz, H. A., Isa, M.H., Zinatizadeh, A. A. (2009): Application of response surface methodology (RSM) to optimize coagulation-flocculation treatment of leachate 
using poly-aluminum chloride (PAC) and alum. - Journal of Hazardous Materials 163(23): 650-656.

[11] Hao, L., Song, H., Zhang, L., Wan, X., Tang, Y., Lv, Y. (2012): SiO2/graphene composite for highly selective adsorption of $\mathrm{Pb}$ (II) ion. - Journal of Colloid and Interface Science 369(1): 381-387.

[12] Hu, X.-J. Liu, Y.-G., Wang, H., Chen, A.W., Zeng, G.-M., Liu, S., Guo, Y.-M., Hu, X., Li, T.-T., Wang, Y., Zhou, L., Liu, S. (2013): Removal of $\mathrm{Cu}(\mathrm{II})$ ions from aqueous solution using sulfonated magnetic graphene oxide composite. - Journal of Separation and Purification Technology 108: 189-195.

[13] Huang, Z., Pan, X. D., Wu, P. G., Han, J. L., Chen, Q. (2014): Heavy metals in vegetables and the health risk to population in Zhejiang, China. - Food Control 36(1): 248-252.

[14] Iram, M., Guo, C., Guan, Y., Ishfaq, A., Liu, H. (2010): Adsorption and magnetic removal of neutral red dye from aqueous solution using $\mathrm{Fe} 3 \mathrm{O} 4$ hollow nanospheres. Journal of Hazardous Materials 181(1-3): 1039-1050.

[15] Jafari Kang, A., Baghdadi, M., Pardakhti, A. (2016): Removal of cadmium and lead from aqueous solutions by magnetic acid-treated activated carbon nanocomposite. Desalination and Water Treatment 57(40): 18782-18798.

[16] Jaishankar, M., Tseten, T., Anbalagan, N., Mathew, B.B., Beeregowda, K. N. (2014): Toxicity, mechanism and health effects of some heavy metals. - Interdisciplinary Toxicology 7(2): 60-72.

[17] Jamali, H. A., Dindarloo, K. and Nikpey, A. (2015): Optimization of metal working fluids treatment using calcium chloride by response surface methodology. - The Journal of Qazvin University of Medical Sciences 19(2): 46-54.

[18] Jiang, J. W., Lan, J., Wang, J. S., Li, B. (2010): Isotopic effects on the thermal conductivity of graphene nanoribbons: Localization mechanism. - Journal of Applied Physics 107(5): 054314.

[19] Jiang, X., Luo, H., Yin, Y., Zhou, W. (2017): Facile synthesis of MoS 2/reduced graphene oxide composites for efficient removal of $\mathrm{Cr}$ (vi) from aqueous solutions. RSC Advances 7(39): 24149-24156.

[20] Khajeh, M. (2011): Optimization of process variables for essential oil components from Satureja hortensis by supercritical fluid extraction using Box-Behnken experimental design. - The Journal of Supercritical Fluids 55(3): 944-948.

[21] Kumar, S., Nair, R. R., Pillai, P. B., Gupta, S. N., Iyengar, M. A. R., Sood, A. K. (2014): Graphene oxide-MnFe2O4 magnetic nanohybrids for efficient removal of lead and arsenic from water. - ACS Applied Materials \& Interfaces 6(20): 17426-17436.

[22] Li, H., Bi, S., Liu, L., Dong, W., Wang, X. (2011): Separation and accumulation of Cu (II), Zn (II) and Cr (VI) from aqueous solution by magnetic chitosan modified with diethylenetriamine. - Desalination 278(1-3): 397-404.

[23] Li, K., Wang, X. (2009): Adsorptive removal of $\mathrm{Pb}$ (II) by activated carbon prepared from Spartina alterniflora: equilibrium, kinetics and thermodynamics. - Bioresource Technology 100(11): 2810-2815.

[24] Li, Q., Yu, L. J., Deng, Y., Li, W., Li, M. T., Cao, J. H. (2007): Leaf epidermal characters of Lonicera japonica and Lonicera confuse and their ecology adaptation. - Journal of Forestry Research 18(2): 103-108.

[25] Lingamdinne, L. P., Koduru, J. R., Choi, Y. L., Chang, Y. Y., Yang, J. K. (2016): Studies on removal of $\mathrm{Pb}$ (II) and $\mathrm{Cr}$ (III) using graphene oxide based inverse spinel nickel ferrite nano-composite as sorbent. - Hydrometallurgy 165: 64-72.

[26] Liu, M., Chen, C., Hu, J., Wu, X., Wang, X. (2011): Synthesis of magnetite/graphene oxide composite and application for cobalt (II) removal. - The Journal of Physical Chemistry C 115(51): 25234-25240. 
[27] McGrail, B. T., Mangadlao, J. D., Rodier, B. J., Swisher, J., Advincula, R., Pentzer, E. (2016): Selective mono-facial modification of graphene oxide nanosheets in suspension. - Chemical Communications 52(2): 288-291.

[28] Omar, H. A., Moloukhia, H. (2008): Use of activated carbon in removal of some radioisotopes from their waste solutions. - Journal of Hazardous Materials 157(2-3): 242246.

[29] Pan, B., Pan, B., Zhang, W., Lv, L., Zhang, Q., Zheng, S. (2009): Development of polymeric and polymer based hybrid adsorbents for pollutants removal from waters. Chemical Engineering Journal 151(1-3): 19-29.

[30] Rajasulochana, P., Preethy, V. (2016): Comparison on efficiency of various techniques in treatment of waste and sewage water - A comprehensive review. - Resource-Efficient Technologies 2(4): 175-184.

[31] Ramana, D. V., Reddy, D. H. K., Yu, J. S., Seshaiah, K. (2012): Pigeon peas hulls waste as potential adsorbent for removal of $\mathrm{Pb}$ (II) and $\mathrm{Ni}$ (II) from water. - Chemical Engineering Journal 197: 24-33.

[32] Ramkumar, J., Chandramouleeswaran, S., Sudarsan, V., Mishra, R. K., Kaushik, C. P., Raj, K., Mukherjee, T., Tyagi, A. K. (2008): Borosilicate glasses modified with organic ligands: A new selective approach for the removal of uranyl ion. - Journal of Hazardous Materials 154(1-3): 513-518.

[33] Sari, A., Tuzen, M. (2009): Kinetic and equilibrium studies of Pb (II) and Cd (II) removal from aqueous solution onto colemanite ore waste. - Desalination 249(1): 260-266.

[34] Sheet, I., Kabbani, A. Holail, H. (2014): Removal of heavy metals using nanostructured graphite oxide, silica nanoparticles and silica/graphite oxide composite. - Energy Procedia 50: 130-138.

[35] Sitko, R., Turek, E., Zawisza, B., Malicka, E., Talik, E., Heimann, J., Gagor, A., Feist, B., Wrzalik, R. (2013): Adsorption of divalent metal ions from aqueous solutions using graphene oxide. - Dalton Transactions 42(16): 5682-5689.

[36] Talib, N. A. A., Salam, F., Yusof, N. A., Ahmad, S. A. A., Sulaiman, Y. (2017): Modeling and optimization of electrode modified with poly (3, 4ethylenedioxythiophene)/graphene oxide composite by response surface methodology/Box-Behnken design approach. - Journal of Electroanalytical Chemistry 787: $1-10$.

[37] Tchounwou, P. B., Yedjou, C. G., Patlolla, A. K., Sutton, D. J. (2012): Heavy Metal Toxicity and the Environment. - In: Luch, A. (ed.) Molecular, Clinical and Environmental Toxicology. Springer, Basel, pp. 133-164.

[38] Tripathi, P., Srivastava, V. C., Kumar, A. (2009): Optimization of an azo dye batch adsorption parameters using Box-Behnken design. - Desalination 249(3): 1273-1279.

[39] Uluozlu, O. D., Sari, A., Tuzen, M., Soylak, M. (2008): Biosorption of Pb (II) and Cr (III) from aqueous solution by lichen (Parmelina tiliaceae) biomass. - Bioresource Technology 99(8): 2972-2980.

[40] Vasudevan, S., Lakshmi, J. (2012): The adsorption of phosphate by graphene from aqueous solution. - RSC Advances 2(12): 5234-5242.

[41] Vasudevan, S., Lakshmi, J., Sozhan, G. (2011): Effects of alternating and direct current in electrocoagulation process on the removal of cadmium from water. - Journal of Hazardous Materials 192(1): 26-34.

[42] Wang, X., Guo, Y., Yang, L., Han, M., Zhao, J., Cheng, X. (2012): Nanomaterials as sorbents to remove heavy metal ions in wastewater treatment. - Environ. Anal. Toxicol 2(7): 1000154.

[43] Yang, Y., Wu, W. Q., Zhou, H. H., Huang, Z. Y., Ye, T. T., Liu, R., Kuang, Y. F. (2014): Adsorption behavior of cross-linked chitosan modified by graphene oxide for $\mathrm{Cu}$ (II) removal. - Journal of Central South University 21(7): 2826-2831. 
[44] Yetilmezsoy, K., Demirel, S., Vanderbei, R. J. (2009): Response surface modeling of Pb (II) removal from aqueous solution by Pistacia vera L.: Box-Behnken experimental design. - Journal of Hazardous Materials 171(1-3): 551-562.

[45] Yu, T., Ni, Z., Du, C., You, Y., Wang, Y., Shen, Z. (2008): Raman mapping investigation of graphene on transparent flexible substrate: The strain effect. - The Journal of Physical Chemistry C 112(33): 12602-12605.

[46] Zarei, H., Mahvi, A. H., Nasseri, S., Nabizadeh Noudehi, R, Shemirani, F. (2015): Modeling adsorption on fluoride and application of Box-Behnken design and response surface methodology for arsenic (V) removal from aqueous solution using Nano-Scale Alumina on Multi Walled Carbon Nanotube. - Iranian Journal of Health and Environment 8(3): 309-322.

[47] Zhao, G., Li, J., Ren, X., Chen, C., Wang, X. (2011): Few-layered graphene oxide nanosheets as superior sorbents for heavy metal ion pollution management. Environmental Science \& Technology 45(24): 10454-10462.

[48] Zhao, G., Ren, X., Gao, X., Tan, X., Li, J., Chen, C., Huang, Y., Wang, X. (2011): Removal of $\mathrm{Pb}$ (II) ions from aqueous solutions on few-layered graphene oxide nanosheets. - Dalton Transaction 40(41): 10945-10952.

[49] Zhao, G., Wen, T., Yang, X., Yang, S., Liao, J., Hu, J., Shao, D., Wang, X. (2012): Preconcentration of $\mathrm{U}(\mathrm{VI})$ ions on few-layered graphene oxide nanosheets from aqueous solutions. - Dalton Transactions 41(20): 6182-6188.

[50] Zhang, K., Li, H., Xu, X., Yu, H. (2018): Synthesis of reduced graphene oxide/NiO nanocomposites for the removal of $\mathrm{Cr}$ (VI) from aqueous water by adsorption. Microporous and Mesoporous Materials 255: 7-14. 